\title{
Last Subject Last Visit Date Time
}

National Cancer Institute

\section{Source}

National Cancer Institute. Last Subject Last Visit Date Time. NCI Thesaurus. Code C142598.

The date and or date and time when the final participant has reached a planned or achieved milestone representing the completion of the trial. 